\title{
STUDI SIFAT FISIOLOGI IKAN GURAMI (Osphronemus gourami) PADASUHU RENDAH UNTUK PENGEMBANGAN TEKNOLOGI TRANSPORTASIIKAN HIDUP
}

\author{
Syamdidi*), Diah Ikasari") dan Singgih Wibowo*)
}

\begin{abstract}
ABSTRAK
Tulisan ini melaporkan tentang studi sifat fisiologi ikan gurami dalam media air yang suhunya diturunkan secara bertahap sebagai dasar penyusunan teknologi transportasi ikan gurami hidup. Metode yang dilakukan adalah dengan menurunkan suhu media air secara bertahap dengan kecepatan $5^{\circ} \mathrm{C} / \mathrm{jam}$ sampai ikan gurami tidak menunjukkan tanda-tanda kehidupan. Pengamatan dilakukan terhadap aktivitas dan metabolisme (respirasi dan produksi metabolit) ikan. Hasil studi menunjukkan bahwa respirasi dan metabolit ikan gurami cenderung menurun seiring dengan makin rendahnya suhu, terutama setelah suhu mencapai $23,6^{\circ} \mathrm{C}$. Pada awal penurunan suhu terjadi sedikit peningkatan respirasi (dari 168,0 menjadi $177,6 \mathrm{mg} \mathrm{O} / \mathrm{kg}$ ikan/jam) kemudian turun dan mencapai titik terendah $\left(1,6 \mathrm{mg} \mathrm{O} / \mathrm{kg}\right.$ ikan/jam) pada suhu $13,6^{\circ} \mathrm{C}$. Pola produksi metabolit serupa dengan pola laju respirasi, yaitu meningkat di awal penurunan suhu $\left(\mathrm{NH}_{3}\right.$ dari 5,76 menjadi $11,52 \mathrm{mg} \mathrm{NH} / \mathrm{kg}$ ikan/jam, dan $\mathrm{NO}_{2}$ dari 0,16 menjadi $0,66 \mathrm{mg} \mathrm{NO} / \mathrm{kg}$ ikan/jam) kemudian turun seiring dengan penurunan suhu $(1,64 \mathrm{mg} \mathrm{NH} / \mathrm{kg}$ ikan/jam dan $0,16 \mathrm{mg} \mathrm{NO} / \mathrm{kg}$ ikan/jam pada suhu $\left.13,6^{\circ} \mathrm{C}\right)$.
\end{abstract}

\begin{abstract}
Study on the physiological characteristics of gouramy (Osphronemus gourami) at low temperature for developing live fish transportation technology. By: Syamdidi, Diah Ikasari and Singgih Wibowo

This paper reports a study on the physiological characteristics of gouramy (Osphronemus gourami) during gradually reduced temperature for developing technology for live fish transportation. The method used in the study was gradual reduction of water temperature at a rate of $5^{\circ} \mathrm{Cl}$ hour until no sign of life of gouramy could be observed. Observation was performed on physical activity and metabolism (respiration and metabolite production) of fish. The results showed that oxygen consumption and metabolism rate tended to decrease as water temperature decreased, especially after water temperature reached $23.6^{\circ} \mathrm{C}$. At the early stage of reducing water temperature, respiration slightly increased (from 168,0 to $177.6 \mathrm{mg} \mathrm{O} / \mathrm{kg}$ of fish/hour) then decreased to the lowest point of $1.6 \mathrm{mg} \mathrm{O} / \mathrm{kg}$ of fish/hour at $13.6^{\circ} \mathrm{C}$. The pattern of metabolites production was similar to the rate of respiration, i.e. increased at the early stage of reducing water temperature $\left(\mathrm{NH}_{3}\right.$ increased from 5.76 to $11.52 \mathrm{mg} \mathrm{NH} / \mathrm{kg}$ of fish/hour, and $\mathrm{NO}_{2}$ increased from 0.16 to $0.66 \mathrm{mg}$ $\mathrm{NO}_{2} / \mathrm{kg}$ of fish/hour) and decreased as water temperature decreased (1.64 $\mathrm{mg} \mathrm{NH}_{3} / \mathrm{kg}$ of fish/hour and $0.16 \mathrm{mg} \mathrm{NO} / \mathrm{kg}$ of fish/hour at $13.6^{\circ} \mathrm{C}$ ).
\end{abstract}

KEYWORDS: gouramy, physiology, low temperature, respiration, live transportation

\section{PENDAHULUAN}

Permintaan konsumen akan ikan diperkirakan akan meningkat secara nyata sehubungan dengan adanya endemi penyakit berbahaya pada hewan ternak seperti anthrax yang menyerang sapi dan flu burung yang menyerang unggas (Anon., 2006). Peningkatan tersebut juga disebabkan oleh adanya pergeseran permintaan akibat ketakutan konsumen untuk mengkonsumi sumber protein hewani berkolesterol tinggi seperti yang terdapat pada daging merah (red meat).
Namun demikian, muculnya kasus penggunaan bahan illegal untuk mengawetkan ikan laut hasil tangkapan, seperti penggunaan formalin yang terjadi belakangan ini, akan mendorong konsumen mengalihkan permintaannya pada ikan hidup, terutama ikan air tawar. Salah satu jenis ikan air tawar yang banyak digemari adalah ikan gurami (Osphronemus gourami) yang lazim dijual dalam keadaan hidup karena ikan gurami hidup dijual dengan harga dua hingga tiga kali lipat dari harga ikan yang sudah mati. Oleh karena itu, pembudidaya ikan gurami

Peneliti pada Balai Besar Riset Pengolahan Produk dan Bioteknologi Kelautan dan Perikanan 
berusaha menjualnya dalam keadaan hidup. Untuk itu, diperlukan teknik transportasi ikan hidup yang dapat menjamin ikan sampai ke konsumen dalam keadaan masih hidup.

Teknik transportasi ikan gurami hidup yang biasa digunakan masyarakat adalah sistem basah menggunakan wadah blong atau drum plastik. Upaya untuk meningkatkan kapasitas angkut telah dilakukan dengan mengurangi jumlah air yang digunakan dan/ atau meningkatkan jumlah ikan yang diangkut. Namun demikian, upaya tersebut masih belum diikuti dengan upaya untuk meningkatkan ketahanan hidup ikan sehingga masih banyak masalah yang dihadapi. Pengurangan jumlah air dan/atau peningkatan jumlah ikan tersebut beresiko meningkatkan aktivitas fisik ikan selama transportasi yang menyebabkan peningkatan kerusakan fisik akibat gesekan antar ikan atau antara ikan dengan wadahnya. Ikan yang mengalami kerusakan fisik tersebut sangat rentan terhadap serangan bakteri dan jamur yang berasal dari lingkungan sehingga ketahanan hidup ikan pasca transportasi tidak lama, yaitu kurang dari 3 hari (Hardaningsih, 2005).

Penggunaan suhu rendah untuk transportasi ikan hidup terbukti cukup efektif untuk mengurangi aktivitas ikan selama transportasi dan meningkatkan ketahanan hidup ikan (Wibowo et al., 1994; 2002). Sebagaimana diketahui, perlakuan penurunan suhu dapat menekan respirasi dan aktivitas ikan (Fry \& Norris 1962; Huet 1972; Suseno 1985; Basyarie 1990; Muchari 1990; Praseno 1990). Lebih dari itu, penggunaan suhu rendah juga memungkinkan ikan dapat ditransportasikan dengan menggunakan media bukan air, seperti misalnya serbuk gergaji lembab yang didinginkan.

Teknik imotilisasi dengan suhu rendah dipandang aman, ekonomis dan efektif untuk ikan dan telah dilakukan pada udang windu, lobster (Wibowo et al., 1994) dan kerapu (Wibowo et al., 2002). Mengingat telah berhasil diterapkan pada ikan kerapu, diharapkan teknik tersebut juga dapat diterapkan pada ikan gurami. Meskipun demikian, masih diperlukan pengujian karena gurami memiliki sistem pernapasan agak berbeda dari ikan yang lain. Selain insang, gurami memiliki alat pernapasan tambahan yaitu labyrinth yang memungkinkan ikan gurami dapat mengambil oksigen dari udara bebas di luar permukaan air (Rahardjo \& Murniarti, 1984). Akibatnya, di habitatnya ikan gurami secara periodik selalu muncul ke permukaan air untuk mengambil oksigen bebas (Prihartono, 2004).

Untuk menguji apakah teknik imotilisasi dengan suhu rendah tersebut dapat diterapkan pada gurami, diperlukan informasi dasar tentang sifat fisiologi gurami pada suhu rendah, terutama aktivitas fisik, respirasi dan metabolisme. Sejauh ini, studi dan publikasi tentang hal ini belum tersedia sehingga tidak mudah untuk menentukan kondisi yang sesuai untuk transportasi hidup ikan gurami. Studi ini ditujukan untuk mempelajari sifat fisiologis ikan gurami yang hasilnya diharapkan dapat digunakan sebagai informasi dasar untuk transportasi hidup ikan tersebut. Penelitian ditekankan untuk mempelajari pola aktivitas fisik dan metabolisme (respirasi dan produksi metabolit) ikan gurami pada berbagai suhu rendah.

\section{BAHAN DAN METODE}

\section{Bahan}

Bahan utama yang digunakan dalam penelitian ini adalah ikan gurami (Osphronemus gourami) dari Purwokerto yang sudah diseleksi yaitu dalam keadaan sehat, anggota tubuh dan sisik lengkap dengan ukuran 300-400 g/ekor yang kemudian ditampung untuk dibugarkan dan dipuasakan selama 1 hari. Bahan lain yang digunakan adalah es batu, reagent test kit untuk analisis mutu air (Hach Colorimeter), akuades dan akuabides.

Peralatan yang digunakan dalam penelitian terbagi menjadi dua yaitu peralatan untuk percobaan dan peralatan untuk analisis. Peralatan untuk percobaan adalah respirometer multi suhu hasil disain Balai Besar Riset Pengolahan Produk dan Bioteknologi Kelautan dan Perikanan (Wibowo et al., 1994). Respirometer terbuat dari bahan akrilik berbentuk akuarium persegi empat berukuran $60 \times 60 \times 40 \mathrm{~cm}$ dengan total volume $48 \mathrm{~L}$, dilengkapi dengan pompa sirkulator, aerator, DO meter (YSI) dan termometer serta tutup berbentuk kerucut. Alat ini dilengkapi dengan outlet dan inlet untuk memasukkan dan mengeluarkan air.

Peralatan untuk analisis terdiri atas timbangan (Lion Star), pencatat waktu (timer), test kit untuk analisis mutu air (Hach Colorimeter) dan peralatan lain untuk analisis kandungan $\mathrm{NH}_{3}$ dan $\mathrm{NO}_{2}$ terlarut.

\section{Metode}

Ikan gurami sebanyak 5 ekor dibugarkan dan dipuasakan dalam bak penampungan pada suhu lingkungan $\left(29 \pm 0,2^{\circ} \mathrm{C}\right)$ kemudian ditimbang lalu dimasukkan ke dalam respirometer yang telah diisi air sampai penuh, kemudian pompa sirkulator dan aerator dioperasikan. Suhu air diturunkan secara bertahap dengan mengalirkan air dingin $\left(0-1^{\circ} \mathrm{C}\right) \mathrm{ke}$ dalam respirometer. Kecepatan penurunan suhu diatur sebesar $5^{\circ} \mathrm{C} / \mathrm{jam}$ (Berka, 1986; Wibowo et al., 1994; 2002). Pengamatan dilakukan setiap 30 menit terhadap aktivitas dan metabolisme ikan gurami. 
Setelah penurunan suhu selama 30 menit, aerator dan pompa sirkulator dimatikan, gelembung udara yang menempel di dinding respirometer dibersihkan kemudian respirometer ditutup rapat sehingga tidak terjadi kontak antara udara dengan air. Kondisi ini dipertahankan selama 10 menit dan selama itu dilakukan pengamatan oksigen terlarut setiap 5 menit (menit ke 0,5, dan 10), serta pengukuran kandungan metabolit $\left(\mathrm{NH}_{3}\right.$ dan $\left.\mathrm{NO}_{2}\right)$ pada menit ke-0 dan ke-10. Sampel air untuk pengukuran kandungan metabolit dikeluarkan melalui outlet respirometer.

Setelah selesai pengamatan, respirometer dibuka, sirkulator dan aerator dihidupkan kembali dan penurunan suhu dilanjutkan. Perlakuan ini dilakukan secara berulang dengan prosedur yang sama sampai aktivitas ikan gurami melemah hingga akhirnya tidak menunjukkan tanda-tanda kehidupan lagi. Percobaan tersebut dilakukan dengan dua kali ulangan.

Aktivitas ikan diamati selama proses penurunan suhu yang meliputi gerakan ikan di dalam air, respon terhadap rangsangan dari luar dan respon terhadap sentuhan (yang diberikan menggunakan batang bambu kecil diameter $0,25 \mathrm{~cm}$ yang dibungkus dengan selang plastik) (Wibowo et al., 1994; 2002). Metabolisme ikan diamati berdasarkan laju respirasi (konsumsi oksigen) dan produksi metabolit $\left(\mathrm{NH}_{3}\right.$ dan $\mathrm{NO}_{2}$ ). Respirasi ikan dihitung dari selisih kandungan oksigen terlarut $(\mathrm{mg})$ pada saat aerasi dihentikan (menit ke-0) dan setelah 10 menit (menit ke-10) dibagi dengan bobot ikan $(\mathrm{Kg})$ kemudian dikonversikan ke dalam satuan jam. Total produksi metabolit $\left(\mathrm{NH}_{3}\right.$ dan $\mathrm{NO}_{2}$ ) dihitung berdasarkan selisih kandungan metabolit pada awal (menit ke-0) dan akhir pengamatan (menit ke-10) yang terdapat dalam $48 \mathrm{~L}$ air di dalam respirometer, dibagi bobot ikan $(\mathrm{Kg})$ kemudian dikonversikan ke dalam satuan jam.

\section{HASIL DAN BAHASAN}

\section{Aktivitas Ikan Gurami}

Aktivitas ikan gurami dalam merespon perubahan suhu air yang diturunkan secara bertahap tampaknya berlangsung dalam beberapa fase atau tahap (Tabel 1).

Fase pertama adalah fase ikan beradaptasi terhadap lingkungan barunya. Pada saat itu suhu media masih $29,2^{\circ} \mathrm{C}$. Pada fase adaptasi ini ikan kembali normal meskipun pada awalnya tampak stres. Ketika suhu diturunkan hingga $26,1^{\circ} \mathrm{C}$, ikan masih berusaha beradaptasi terhadap suhu lingkungan yang makin rendah.

Fase selanjutnya adalah fase awal mulai terjadinya kehilangan keseimbangan yaitu terjadi pada suhu $26,1^{\circ} \mathrm{C}$, namun ikan masih cukup responsif. Pada suhu yang lebih rendah, respon ikan terhadap rangsangan mulai lemah, dan mulai menunjukkan hilangnya keseimbangan dengan rebah di dasar media.

Fase berikutnya adalah fase aktivasi yang terjadi pada suhu $21,1-18,6^{\circ} \mathrm{C}$ ditandai dengan cukup responsifnya ikan terhadap rangsangan dari luar dan berenang ke atas permukaan.

Fase lebih lanjut adalah fase hilang keseimbangan dan pingsan yang ditunjukkan oleh kondisi ikan yang kehilangan keseimbangan dan rebah di dasar. Fase tersebut terjadi pada suhu $18,6-16,1^{\circ} \mathrm{C}$.

Fase terakhir adalah fase pingsan, yaitu ikan rebah di dasar dengan gerakan-gerakan yang lemah yang mulai teramati pada suhu $16,1^{\circ} \mathrm{C}$. Pada saat mendekati suhu $13,6^{\circ} \mathrm{C}$, tanda-tanda kehidupan tidak terlihat lagi. Pada titik suhu terakhir ini $\left(13,6^{\circ} \mathrm{C}\right)$, kepastian bahwa ikan hidup atau mati tidak dapat diperoleh sehingga dapat dianggap sebagai titik suhu awal kematian ikan.

Berdasarkan hasil tersebut di atas, dapat ditentukan kisaran suhu yang berpeluang untuk transportasi ikan gurami hidup. Kisaran suhu tersebut adalah $23-16^{\circ} \mathrm{C}$ yang tampaknya tidak jauh berbeda dengan kisaran suhu untuk ikan kerapu yaitu $21-17^{\circ} \mathrm{C}$ (Wibowo et al., 2002). Namun demikian, di dalam kisaran suhu tersebut, terdapat satu fase yang perlu mendapat perhatian, yaitu pada kisaran suhu 21,1$18,6^{\circ} \mathrm{C}$ karena ikan mengalami aktivasi.

Hasil lain yang menarik adalah adanya kebiasaan ikan gurami untuk selalu mencari permukaan (Tabel 1). Hasil serupa juga diperoleh ketika dilakukan observasi awal. Pada dasarnya, ikan gurami termasuk ikan yang sensitif terhadap suhu dingin dan kondisi media tertutup. Di lingkungan habitatnya, ikan gurami mempunyai kebiasaan secara periodik muncul ke permukaan air untuk mengambil oksigen karena selain bernafas dengan mengambil oksigen terlarut dalam air, ikan gurami juga bernafas dengan mengambil oksigen bebas di udara (Prihartono, 2004). Kondisi respirometer yang tertutup membuat ikan gurami cenderung gelisah meskipun oksigen terlarut dalam air masih cukup tinggi yaitu $4,74-5,99 \mathrm{mg} / \mathrm{l}$. Hal ini disebabkan karena ikan tidak dapat muncul ke permukaan untuk mengambil oksigen bebas di udara. Oleh karena itu, pemberian akses ke permukaan air perlu disediakan dalam merancang transportasi gurami hidup dengan sistem basah. Misalnya, dengan memberikan ruang kosong antara permukaan air dan tutup wadah. 
Tabel 1. Suhu media yang terukur pada setiap fase perubahan aktivitas ikan gurami

Table 1. Temperature of media observed at each phase of gouramy activity changes

\begin{tabular}{lcc}
\hline $\begin{array}{l}\text { Fasel } \\
\text { phase }\end{array}$ & Aktivitas gurami/Gouramy activities & $\begin{array}{c}\text { Suhu/ } \\
\text { Temperature }\left({ }^{\circ} \mathrm{C}\right)\end{array}$
\end{tabular}

1 Pada menit pertama saat dimasukkan ke dalam media baru (air), ikan 29.2 bergerak aktif ke permukaan, kemudian gerakan mulai tidak teratur, sirip merenggang, ekor kemerahan. Ikan masih responsif terhadap rangsangan dari luar, aktif berenang menuju permukaan dan membentur tutup respirometer, turun kembali dan berenang tak beraturan, kemudian tenang dan ikan kembali normal/At the first minute when transferred into its new media, gouramy actively swam to water surface, then swam irregularly, ventral fins stretched, caudal fins was reddish. Fish was still responsive to outside stimulation, swam to the top and hit respirometer cap, swam irregularly to the bottom, but then swam normally

2 Ikan mulai hilang keseimbangan tetapi masih aktif bergerak, respon $29.2-26.1$ terhadap rangsangan yang diberikan mulai berkurang, gerakan sirip dan operkulum mulai melemah. Ikan selalu bergerak mencari akses ke permukaan/Fish started loosing its balance, response to stimulation decreased, but still actively moved. Fins and operculum movement weakened. Fish kept trying to access to the surface

$3 \quad$ Ikan masih responsif terhadap rangsangan yang diberikan, namun mulai $26.1-23.6$ melemah. Operkulum bergerak lemah. Ikan mulai rebah di dasar, pergerakan melemah dan tidak teratur, warna memucat. Upaya mendapatkan akses ke permukaan tampak jelas terlihat. Di akhir pengamatan ikan rebah di dasar/Fish was still responsive to stimulation given, but started to response weakly. Operculum moved weakly. Fish laid at the bottom, fish movement weakened, and was pale. Effort of fish to get access to the surface was clearly noted. At the end of observation fish laid at the bottom

$4 \quad$ Operkulum bergerak lemah, ikan rebah di dasar dan berenang ke atas $23.6-21.1$ ketika mendapat rangsangan dari luar kemudian rebah kembali di dasar. Upaya mendapatkan akses ke permukaan tampak jelas terlihat/Overculum moved weakly, fish laid at the bottom and moved up on outside stimulation and then went down to the bottom. Effort of fish to get access to the surface was clearly noted

5 Ikan responsif terhadap rangsangan dari luar (namun di akhir $21.1-18.6$ pengamatan respon makin melemah) dan langsung berenang naik ke permukaan, tenang kembali dan rebah di dasar. Warna punggung menjadi lebih gelap. Upaya mendapatkan akses ke permukaan mulai berkurang/Fish was responsive to outside stimulation (but finally responded weakly) by moving directly to the surface spontaneously, calm and laid at the bottom. Ventral of the fish darkened. Effort of fish to get access to the surface was slower 
Tabel 1. Suhu media yang terukur pada setiap fase perubahan aktivitas ikan gurami (lanjutan)

Table 1. Temperature of media observed at each phase of gouramy activity changes (continue)

\begin{tabular}{llc}
\hline $\begin{array}{l}\text { Fase/ } \\
\text { phase }\end{array}$ & Aktivitas gurami/Gouramy activities & $\begin{array}{c}\text { Suhu/ } \\
\text { Temperature }\left({ }^{\circ} \mathrm{C}\right)\end{array}$ \\
\hline
\end{tabular}

6 Gerakan ikan lemah, respon terhadap rangsangan dari luar lemah.

$18.6-16.1$

Tubuh tidak dapat tegak, hilang keseimbangan, bergerak tidak teratur, kemudian turun ke bawah kembali. Sesekali keluar gelembung dari tapis insangnya. Upaya mendapatkan akses ke permukaan sangat lemah/Fish movement was getting weak, less responsive to moving object. Fish lost its balance while moving uncontrollable then went down to the bottom. Air bubble was out from the gills. Effort of fish to get access to the surface was very weak

7 Ikan menggerak-gerakkan tubuhnya, kemudian rebah lagi. Mengeluarkan gelembung dari tapis insang, tidak memberikan respon terhadap rangsangan dari luar. Ikan tidak menunjukkan ada pergerakan sama sekali/Fish moved, went down again. Air bubble was expelled from the gills, no more response when touched. No sign of life fish could be detected

\section{Metabolisme Ikan Gurami}

\section{Respirasi}

Pengaruh penurunan suhu air secara bertahap terhadap respirasi ikan gurami yang dihitung berdasarkan oksigen yang dikonsumsi disajikan pada Gambar 1. Pola laju respirasi ikan gurami cenderung menurun seiring dengan laju penurunan suhu. Pola ini sesuai dengan kenyataan yang selama ini terjadi, yaitu bahwa perlakuan penurunan suhu dapat menekan respirasi dan aktivitas ikan (Fry \& Norris 1962; Huet 1972; Suseno 1985; Basyarie 1990; Muchari 1990; Praseno 1990; Wibowo et al., 1994; 2002).

Laju konsumsi oksigen pada menit awal perlakuan cukup tinggi. Hal ini tampaknya karena ikan gurami masih dalam tahap adaptasi terhadap lingkungan baru sehingga cenderung gelisah dan mengarah ke panik. Ikan yang gelisah dan panik memerlukan energi lebih banyak dan salah satu sumber energinya adalah oksigen (Winarno, 2003). Setelah proses adaptasi, ikan cenderung lebih tenang dan berusaha untuk menyesuaikan diri dengan lingkungan baru. Menurut Affandi \& Usman (2002), dalam rangka menyesuaikan diri dengan lingkungan, hewan memiliki toleransi dan resistensi pada kisaran tertentu dari variasi lingkungannya.
Dari hasil percobaan, total konsumsi oksigen pada suhu $23,6^{\circ} \mathrm{C}$ sebesar $177,60 \mathrm{mg} / \mathrm{kg}$ ikan $/ \mathrm{jam}$ kemudian pada suhu suhu $21,1^{\circ} \mathrm{C}$ turun menjadi 141,12 $\mathrm{mg} / \mathrm{kg}$ ikan/jam dan turun cukup drastis pada suhu $18,6^{\circ} \mathrm{C}$ tinggal sebesar $85,44 \mathrm{mg} / \mathrm{kg}$ ikan/jam. Perbedaan tingkat konsumsi oksigen pada rentang suhu ini berhubungan dengan aktivitas ikan yang mulai hilang keseimbangan, tidak banyak gerakan dan cenderung rebah di dasar.

Tingkat konsumsi oksigen pada suhu $16,1^{\circ} \mathrm{C}$ hampir sama dengan tingkat konsumsi oksigen pada suhu $18,6^{\circ} \mathrm{C}$ yaitu sebesar $85,44 \mathrm{mg} / \mathrm{kg}$ ikan/ jam. Pada suhu ini, aktivitas tidak banyak berubah sehingga energi yang dibutuhkan hampir sama. Ikan hilang keseimbangan dan rebah walaupun masih memberikan respon lemah terhadap rangsangan. Pada suhu $13,6^{\circ} \mathrm{C}$, laju konsumsi oksigen sangat rendah yaitu sebesar $1,60 \mathrm{mg} / \mathrm{kg}$ ikan/jam dan pada suhu ini sudah tidak tampak adanya tanda-tanda kehidupan lagi karena aktivitas ikan hampir tidak ada. Kisaran suhu yang berpeluang untuk pemanfaatan transportasi ikan gurami hidup adalah suhu $23-16^{\circ} \mathrm{C}$. Pada kisaran suhu tersebut, laju respirasi ikan gurami mulai menurun. Kondisi seperti ini sangat menguntungkan dalam transportasi karena pasokan oksigen dalam media kemasan selama transportasi sangat terbatas. 


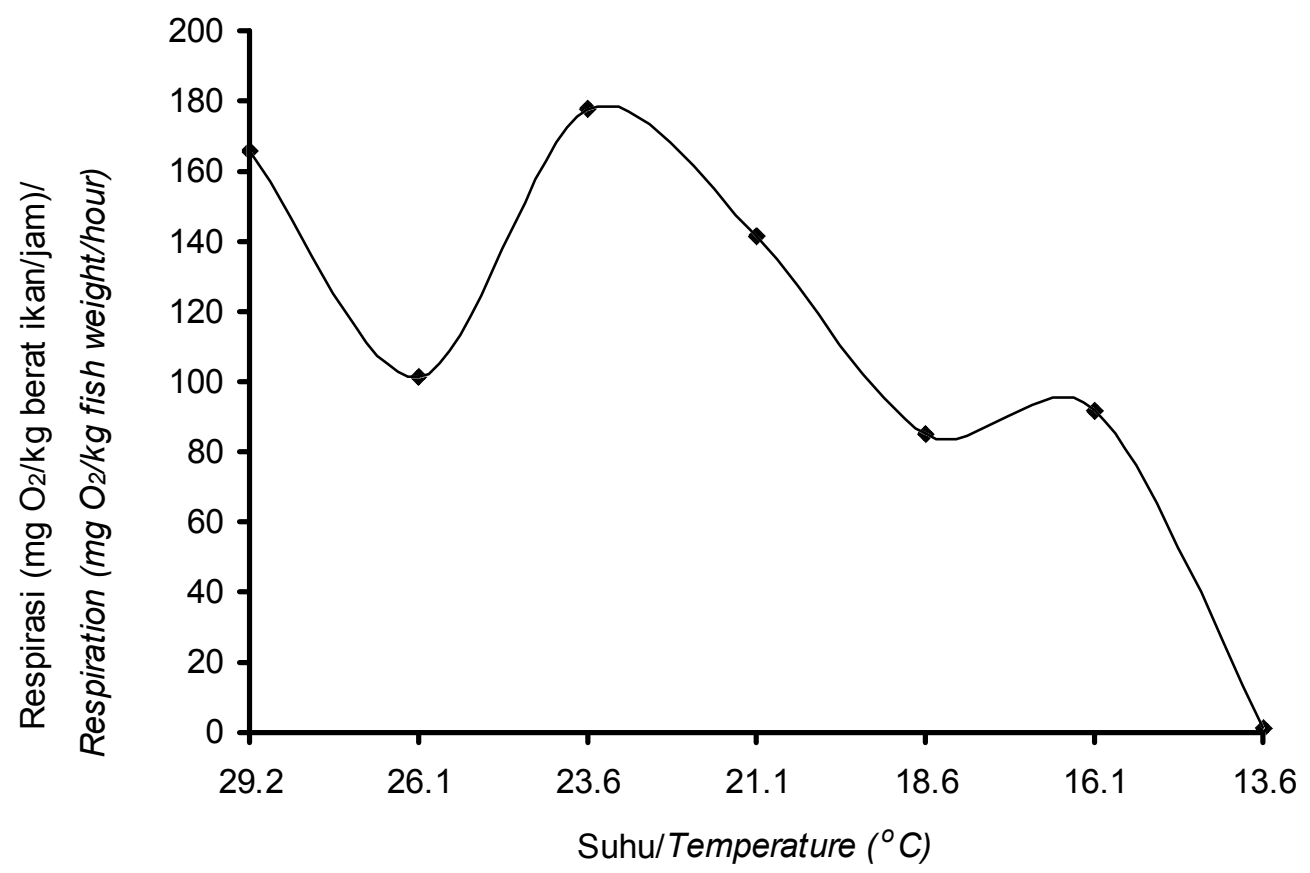

Gambar 1. Pola respirasi ikan gurami hidup pada berbagai suhu rendah.

Figure 1. Respiration pattern of gouramy at various low temperatures.

\section{Produksi amonia $\left(\mathrm{NH}_{3}\right)$}

Pola laju metabolisme ikan gurami selama perlakuan hampir sama dengan pola respirasinya yakni cenderung menurun (Gambar 2). $\mathrm{Nilai}^{\mathrm{NH}_{3}}$ terlarut pada awal percobaan sebesar $0,035 \mathrm{mg} / \mathrm{L}$. Total produksi $\mathrm{NH}_{3}$ pada awal percobaan tersebut adalah $5,76 \mathrm{mg}$ $\mathrm{NH}_{3} / \mathrm{kg}$ ikan/jam lalu meningkat menjadi $11,52 \mathrm{mg} / \mathrm{kg}$ ikan/jam ketika suhu mencapai $23,6^{\circ} \mathrm{C}$. Hasil ini tampaknya memiliki korelasi dengan aktivitas dan laju respirasi ikan gurami.

Aktivitas ikan di awal percobaan cenderung menunjukkan gejala gelisah sebagai proses adaptasi dengan tingkat konsumsi oksigen cukup tinggi. Ikan yang gelisah memerlukan oksigen yang cukup tinggi dibandingkan dengan ikan yang tenang (Winarno, 2003). Akibatnya, kandungan oksigen menjadi terbatas sebagai akibat konsumsi secara terus menerus dalam media uji sehingga membuat ikan gurami berusaha untuk menjaga keseimbangan homeostasis dengan mengeluarkan energi lebih besar yang berujung dengan munculnya gejala stres (Heath, 1987). Kondisi stres ini akan menstimulasi lapisan luar adrenalin mengeluarkan sejumlah kortisol dan memacu perubahan protein tubuh menjadi asam amino yang kemudian akan terurai menjadi amonia (Heath,
1987). Akibatnya, produksi amoniak pada kondisi tersebut akan meningkat sebagaimana tampak pada hasil penelitian ini.

Penurunan suhu dari $23,6^{\circ} \mathrm{C}$ ke $21,1^{\circ} \mathrm{C}$ telah mampu menurunkan produksi $\mathrm{NH}_{3}$ dari 11,52 menjadi $4,94 \mathrm{mg} \mathrm{NH} / \mathrm{kg}$ ikan/jam. Jika dikaitkan dengan aktivitasnya, penurunan produksi $\mathrm{NH}_{3}$ pada suhu ini berhubungan dengan aktivitas ikan gurami yang mulai tenang kemudian rebah di dasar media uji (Tabel 1). Akan tetapi, ketika suhu diturunkan kembali hingga mencapai $18,6^{\circ} \mathrm{C}$, produksi $\mathrm{NH}_{3}$ meningkat $(8,23 \mathrm{mg}$ $\mathrm{NH}_{3} / \mathrm{kg}$ ikan/jam). Peningkatan produksi $\mathrm{NH}_{3}$ ini tampaknya berkaitan dengan aktivitas ikan yang responsif. Penurunan suhu lebih lanjut telah menekan kembali produksi $\mathrm{NH}_{3}$ dan mencapai titik terendah 1,64 $\mathrm{mg} \mathrm{NH}_{3} / \mathrm{kg}$ ikan/jam pada suhu $13,6^{\circ} \mathrm{C}$ ketika ikan sudah rebah dan tidak tampak adanya tanda-tanda kehidupan.

Apabila dilihat dari pola produksi $\mathrm{NH}_{3}$ tersebut di atas, kisaran suhu yang berpeluang untuk digunakan dalam transportasi ikan gurami hidup adalah suhu 23$16^{\circ} \mathrm{C}$ karena pada suhu ini produksi $\mathrm{NH}_{3}$ cenderung menurun. Namun demikian, di antara kisaran suhu tersebut, suhu $21-19^{\circ} \mathrm{C}$ perlu mendapat perhatian karena pada suhu tersebut terjadi sedikit peningkatan produksi $\mathrm{NH}_{3}$. Apabila peningkatan kandungan $\mathrm{NH}_{3}$ 


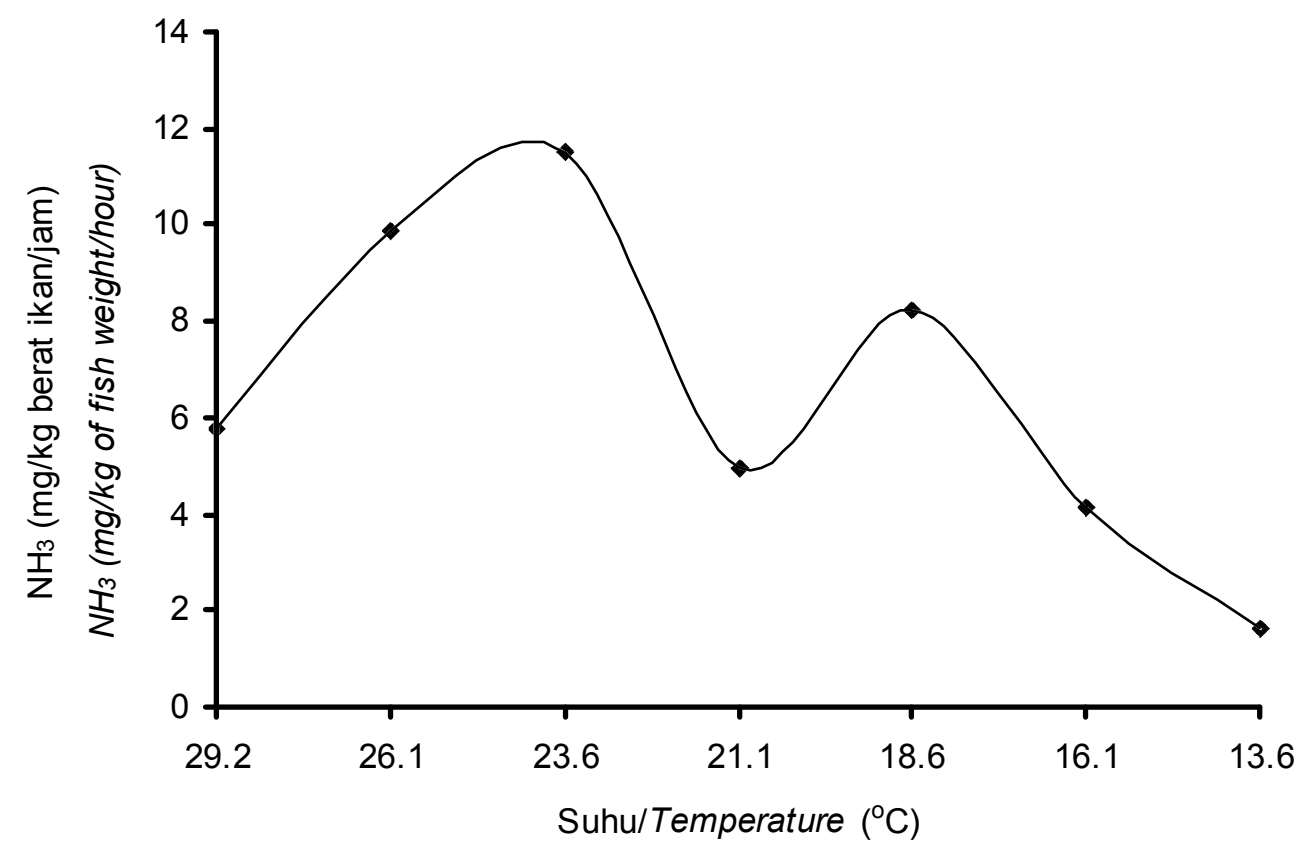

Gambar 2. Pola produksi $\mathrm{NH}_{3}$ sebagai produk metabolit ikan gurami pada berbagai suhu rendah. Figure 2. Pattern of $\mathrm{NH}_{3}$ as a metabolite products of gouramy at various low temperatures.

dalam media air terjadi selama transportasi, penggantian sebagian air untuk mengurangi konsentrasi $\mathrm{NH}_{3}$ yang tinggi dapat dilakukan.

\section{Produksi nitrit $\left(\mathrm{NO}_{2}\right)$}

Pola laju produksi $\mathrm{NO}_{2}$ menurun selama perlakuan penurunan suhu air media hidupnya (Gambar 3). Seperti halnya amonia $\left(\mathrm{NH}_{3}\right)$, nitrit $\left(\mathrm{NO}_{2}\right)$ merupakan senyawa yang bersifat toksik yang merupakan hasil penguraian senyawa organik yang dapat berasal dari metabolisme gurami atau pun pakan. Dalam percobaan ini tidak ada perlakuan pemberian pakan sehingga pembentukan nitrit lebih banyak berasal dari hasil metabolisme. Nitrit merupakan hasil reduksi senyawa nitrat $\left(\mathrm{NO}_{3}\right)$ dan atau oksidasi amonia $\left(\mathrm{NH}_{3}\right)$ oleh mikroorganisme (Hutagalung et al., 1997).

Pola laju pembentukan nitrit yang tampak pada Gambar 3 serupa dengan laju pembentukan amonia (Gambar 2). Pada awal percobaan (suhu $29,2^{\circ} \mathrm{C}$ ), kandungan $\mathrm{NO}_{2}$ terlarut adalah $0,001 \mathrm{mg} / \mathrm{L}$. Total produksi $\mathrm{NO}_{2}$ di awal percobaan tersebut $\left(29,2^{\circ} \mathrm{C}\right) 0,16$ $\mathrm{mg} \mathrm{NO}_{2} / \mathrm{kg}$ ikan/jam yang kemudian meningkat dan mencapai puncaknya $(0,66 \mathrm{mg} / \mathrm{kg}$ ikan/jam) ketika suhu mencapai $23,6^{\circ} \mathrm{C}$. Penurunan suhu lebih lanjut hingga suhu mencapai $21,1^{\circ} \mathrm{C}$ ternyata telah menyebabkan penurunan secara tajam produksi $\mathrm{NO}_{2}$ $(0,16 \mathrm{mg} / \mathrm{kg} \mathrm{ikan} / \mathrm{jam})$. Pola produksi $\mathrm{NO}_{2}$ pada penurunan suhu lebih lanjut (di bawah $21,1^{\circ} \mathrm{C}$ ) relatif stabil hingga suhu $13,6^{\circ} \mathrm{C}$.

Pembentukan $\mathrm{NO}_{2}$ dalam air dipengaruhi oleh kandungan oksigen bebas $\left(\mathrm{O}_{2}\right)$, sementara itu penguraian bahan organik oleh mikroorganisme membutuhkan oksigen dalam jumlah banyak. Apabila oksigen bebas tidak cukup, maka oksigen tersebut diambil dari senyawa nitrat $\left(\mathrm{NO}_{3}\right)$ sehingga $\mathrm{NO}_{3}$ tersebut berubah menjadi $\mathrm{NO}_{2}$ (Hutagalung, 1997). Kandungan oksigen terlarut di kisaran suhu 21 , $13,6^{\circ} \mathrm{C}$ pada penelitian ini cukup tinggi $(7,87-8,08$ $\mathrm{mg} / \mathrm{l}$ ) sehingga kemungkinan pembentukan $\mathrm{NO}_{2}$ dari nitrat oleh mikroorganisme kecil karena cukup tersedia banyak oksigen bagi metabolisme. Dengan demikian, diperkirakan bahwa produksi $\mathrm{NO}_{2}$ tersebut merupakan metabolit ikan gurami. Berdasarkan hasil pengamatan produksi $\mathrm{NO}_{2}$ tersebut, kisaran suhu yang berpeluang untuk digunakan dalam transportasi ikan gurami hidup adalah di bawah $23,6^{\circ} \mathrm{C}$ namun masih di atas $16,1^{\circ} \mathrm{C}$.

Berdasarkan aktivitas ikan, respirasi dan produksi metabolit $\left(\mathrm{NH}_{3}\right.$ dan $\left.\mathrm{NO}_{2}\right)$, maka kisaran suhu yang berpeluang untuk diterapkan dalam transportasi ikan gurami hidup adalah di bawah $23,6^{\circ} \mathrm{C}$ namun masih di atas $16,1^{\circ} \mathrm{C}$. Penggunaan suhu di luar kisaran suhu tersebut tidak disarankan karena suhu yang lebih tinggi dapat menyebabkan ikan memproduksi 


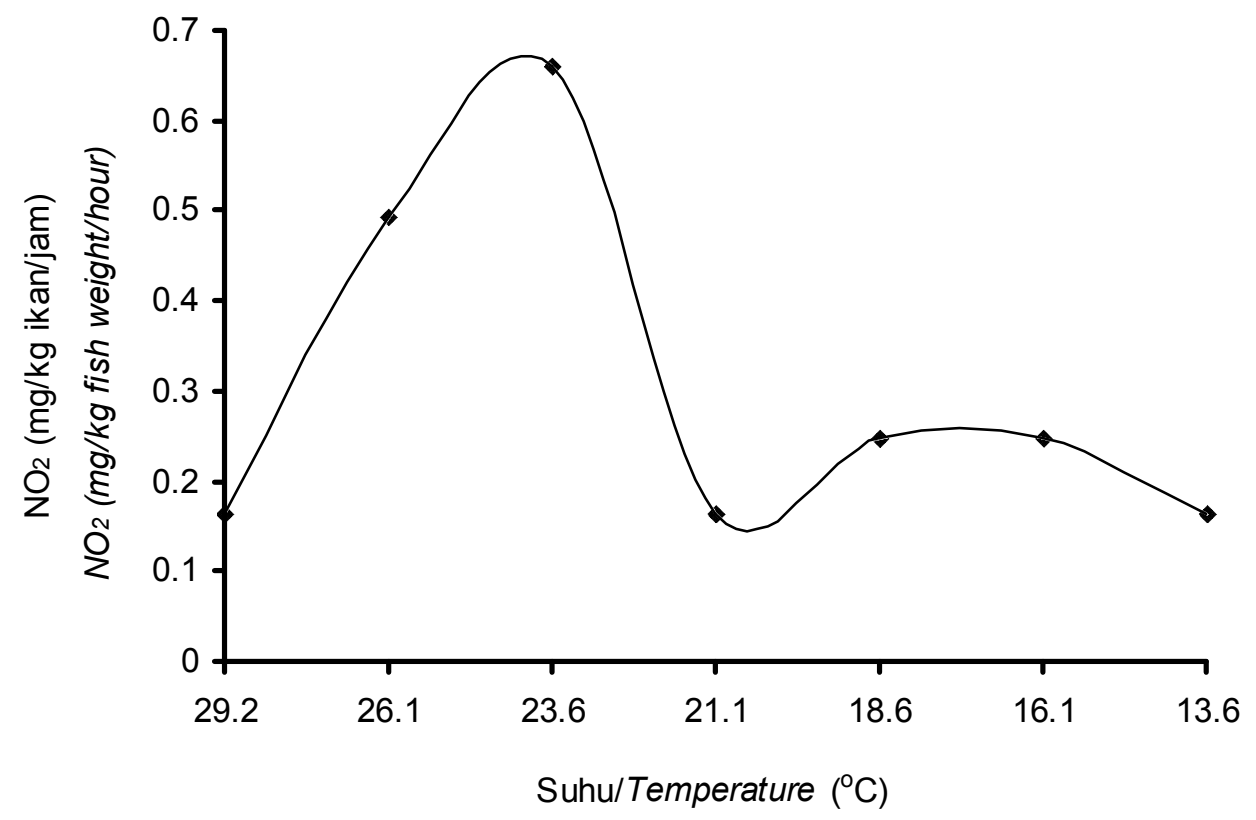

Gambar 3. Pola produksi $\mathrm{NO}_{2}$ sebagai produk metabolit ikan gurami pada berbagai suhu rendah.

Figure 3. Pattern of $\mathrm{NO}_{2}$ as a metabolite products of gouramy at various low temperatures.

metabolit dalam jumlah banyak dan dapat berakibat ikan keracunan metabolit. Sebagai pedoman, di tempat pemeliharaan, batas toleransi gurami terhadap $\mathrm{NH}_{3}$ antara $0,6-3,8 \mathrm{mg} / \mathrm{L}$ pada suhu $30^{\circ} \mathrm{C}$. Namun jika kandungan oksigen terlarut tinggi, maka batas toleransi tersebut dapat lebih tinggi (Prihartono, 2004). Sebaliknya, apabila suhu terlalu rendah ikan tidak dapat bertahan hidup karena suhu lingkungan berada di bawah batas toleransi ikan.

\section{KESIMPULAN DAN SARAN}

1. Penurunan suhu pada awal perlakuan telah menyebabkan aktivasi laju respirasi dan metabolisme ikan gurami yang kemudian cenderung menurun seiring dengan penurunan suhu air media hidup ikan.

2. Kisaran suhu yang berpeluang untuk digunakan dalam transportasi ikan gurami hidup adalah di bawah $23^{\circ} \mathrm{C}$ namun masih di atas $16^{\circ} \mathrm{C}$. Meskipun demikian, pada suhu $21-19^{\circ} \mathrm{C}$ perlu diwaspadai terjadinya peningkatan $\mathrm{NH}_{3}$.

3. Untuk transportasi ikan gurami dengan sistem basah disarankan untuk tidak menutup permukaan air sehingga terdapat sirkulasi atau pergantian udara di atas permukaan air dan memberikan peluang bagi ikan untuk mendapatkan akses ke permukaan air.

\section{DAFTAR PUSTAKA}

Affandi, R. dan Tang, U. M. 2002. Fisiologi Hewan Air. Unri Press, Pekanbaru. 213 pp.

Anonim. 2006. Seiring wabah flu burung, bisnis perikanan bergairah lagi. Http:// www.kompasjawatengah.com. Diakses 26 April 2006.

Basyarie, A. 1990. Transportasi ikan hidup. Makalah disampaikan pada Training Penangkapan, Aklimatisasi dan Transportasi Ikan Hias Laut, Jakarta. 4-18 Desember 1990. 15 pp.

Berka, R. 1986. The transport of live fish. A review. EIFAC Tech. Pap., FAO. (48): 52

Fry, F.E. and Norris, K.S. 1962. The transportation of live fish. In: Borgstrom, G. (ed.). Fish as Food Vol. II. Academic Press, New York p. 595-608.

Hardaningsih. 2005. Konsultasi pribadi.

Heath, A.G. 1987. Water Pollution and Fish Physiology. Department of Biology, Virginia Polytechnic Institute and State University. Blacksburg, Virginia. CRC Press, Inc. 245 pp.

Huet, M. 1972. Text Book of Fish Culture, Breeding and Cultivation of Fish. Phoenix Press Inc. Quezon City, Philipines. $436 \mathrm{pp}$.

Hutagalung, H.P., Setiapermana, D., dan Riyono, S.H. 1997. Metode Analisis Air Laut, Sedimen dan Biota. Buku 2. Pusat Penelitian dan Pengembangan Oseanologi. LIPI. Jakarta. $182 \mathrm{pp}$.

Muchari. 1990. Faktor-faktor Penting yang harus Dipertimbangkan dalam Melaksanakan 
Aklimatisasi. Sub Balidita Bojonegara. Serang. 12 pp.

Praseno, O. 1990. Cara pengiriman/transportasi ikan dalam keadaan hidup. Makalah disampaikan pada Temu Teknologi Pertanian, Departemen Pertanian Jakarta. $16 \mathrm{pp}$.

Prihartono, R.E. 2004. Permasalahan Gurami dan Solusinya. Penebar Swadaya. Jakarta. 78 pp.

Rahardjo, M.F. dan Murniarti. 1984. Anatomi Beberapa Jenis Ikan Ekonomis Penting di Indonesia. Fakultas Perikanan, Institut Pertanian Bogor. 68 pp.

Suseno, S. 1985. Teknik Penanganan Transportasi Ikan Hidup. Pusdiklatluh Pertanian Ciawi, Bogor. 12 pp.
Wibowo, S., Setiabudi, E., Suryaningrum, T.D., dan Sudrajat, Y. 1994. Pengaruh penurunan suhu bertahap terhadap aktifitas lobster hijau pasir (Panulirus humarus). J. Penel. Perik. Indonesia (79): 24-36.

Wibowo, S., Suryaningrum, T.D., Utomo, B.S.B. 2002. Kajian sifat fisiologis kerapu lumpur (Epinephelus tauvina) sebagai dasar dalam pengembangan teknik transportasi hidup. J. Penel. Perik. Indonesia. 8(6): 1-9.

Winarno, F.G. 2003. Transportasi Hidup Ikan dan Domba. M-brio Press. Bogor. 49 pp. 